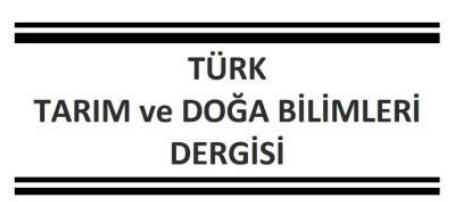

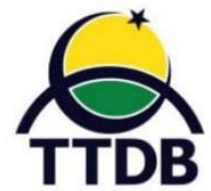

www.dergipark.gov.tr/turkjans

Araştırma Makalesi

\title{
Effects of Supplementation with Iron, Selenium and Magnesium on Galleria mellonella Cell-Mediated Immune Responses
}

\author{
Serhat KAYA*, Bülent GÜNDÜZ \\ Biology Department, Faculty of Arts and Sciences, Çanakkale Onsekiz Mart University, 17100, Çanakkale, Turkey \\ *Corresponding Author: serhatkaya@comu.edu.tr
}

Received: 12.04.2021 Received in revised: 11.06.2021 Accepted: 29.06.2021

\begin{abstract}
Immune responses play a key role in the survival of all living things. Intake of inorganic materials is of critical importance in living organisms because of their participation in metabolism and some component of cells. Iron (Fe), magnesium (Mg) and selenium (Se) were selected for this study because of their participation in critical constituents of cells, such as nucleic acids and enzymes in living organisms, and their indirect and direct effects on immunity. Although the separate effects of these inorganic materials are known, there is no study on their combined effects. Galleria mellonella, which is used as a model organism, is frequently used in evaluating of effects of human pathogens due to its various properties. Total hemocyte counts and encapsulationmelanization responses are the most commonly observed parameters when examining the immune responses of this model organism. In our study, the effects of the selected inorganic materials added in the ratio of $0.1 \%$, $0.25 \%, 0.5 \%$ and $1 \%$ in the nutrient content of $G$. mellonella on the immune responses of this organism were investigated. As a result of the study, it was found that only $0.25 \%$ of the doses increased the hemocyte count and that the other doses significantly decreased compared to the control group. However, it was determined that $0.5 \%$ and $1 \%$ feeding caused a significant decrease in both hemocyte count and encapsulationmelanization responses. According to our findings, the nutrients which have over a certain dose by inorganic substances have negative effects on immunity.
\end{abstract}

Key words: Galleria mellonella, $\mathrm{Fe}, \mathrm{Mg}$, Se, encapsulation-melanization.

\section{Demir, Selenyum ve Magnezyum Desteğinin Galleria mellonella Hücre Aracılı Bağışıklık Tepkileri Üzerindeki Etkileri}

\section{Öz}

Bağışıklık tepkileri, tüm canlıların hayatta kalmasında önemli bir rol oynar. İnorganik materyallerin bünyeye alımı; canlı organizmalarda metabolizmaya ve bazı hücrelerin bileşenlerine katılımları nedeniyle kritik öneme sahiptir. Bu çalışmada demir (Fe), magnezyum $(\mathrm{Mg}$ ) ve selenyum (Se) canlı organizmalardaki nükleik asitler ve enzimler gibi hücrelerin kritik bileşenlerine katılımları ve bağışıklık üzerindeki dolaylı ve doğrudan etkileri nedeniyle seçilmiştir. Bu inorganik maddelerin ayrı ayrı etkilerinin biliniyor olmasına rağmen, bunların birleşik etkileri üzerine bir çalışma bulunmamaktadır. Model organizma olarak kullanılan Galleria mellonella, çeşitli özelliklerinden dolayı insan patojenlerinin etkilerinin değerlendirilmesinde sıklıkla kullanılmaktadır. Çalışmada toplam hemosit sayımları, kapsülleme-melanizasyon bağışıklık tepkileri, incelenmiş olup $G$. mellonella'nın besin içeriğine \% $0.1, \% 0.25$, \% 0.5 ve \% 1 oranında eklenen seçilmiş inorganik maddelerin, bu organizmanın immün yanıtları üzerindeki etkileri araştırılmıştır. Çalışma sonucunda kontrol grubuna göre dozların sadece \% 0.25'inin hemosit sayısını artırdığı, diğer dozlarla ise önemli ölçüde azaldığı tespit edilmiştir. Bununla birlikte, \% 0.5 ve \% 1 oranları, hem hemosit sayısında hem de kapsülleme-melanizasyon yanıtlarında önemli bir düşüşe neden olmuştur. Bulgularımıza göre inorganik maddeler tarafından belirli bir dozun üzerinde bulunan besinler bağışıklık üzerinde olumsuz etkilere sahiptir.

Anahtar kelimeler: Galleria mellonella, $\mathrm{Fe}, \mathrm{Mg}$, Se, encapsulation-melanization. 


\section{Introduction}

Metals have an important role in vitality processes, and especially the divalent magnesium and calcium ions play important regulatory roles in cells (Anastassopoulou and Theophanides, 1995).

Evidence for acquired immunity in insects is relatively recent (Tassetto et al., 2017), but there is a large literature on their innate immunity. Innate immunity in insects is discussed under two main branches: cell-mediated and humoral (Lavine and Strand, 2002). When invaders (e.g. nematodes, bacteria, viruses, parasitoid eggs) cross physical barriers, they rapidly stimulate cell-mediated immunity, followed by humoral responses. Innate immune responses, which are a conserved feature, have many common features in insects and mammals (Krautz et al., 2014; Sheehan et al., 2018; Cutuli et al., 2019). Cell-mediated immune responses are encapsulation, nodulation and phagositosis (Lavine and Strand, 2002; Dubovskiy et al., 2016). When surface recognition proteins in hemocytes recognize invaders, granulocytes and plasmatocytes accumulate around this invader and form layers, which is known as encapsulation (Pech and Strand, 1996; Lavine and Strand, 2002; Rosalaes, 2011; Dubovskiy et al., 2016). Encapsulation responses occur for multicellular organisms, and encapsulation is almost always followed by melanization processes which is the humoral immune response (Nappi and Christensen, 2005). The melanization process is the most effective of humoral immune responses (Lee and Ansstee, 1995). When hemocyte layers begin to form, enzymatic pathways come into play and the melanin formation occurs (Hillyer, 2016). When the melanin formation (melanization process) is complete, the invader is completely isolated. Hemocytes take an active role in both encapsulation reactions and melanization. The increase in hemocyte count is closely related to encapsulation and melanization immune responses (Kaya et al., 2021a,b). Although insects are known to respond effectively to foreign invaders by the encapsulation response, the association between some important ions and immune function is poorly understood (Sorvari et al., 2014). Among these metals, iron, magnesium and selenium draw attention in insect immunity.

Iron is essential for the survival of almost all organisms, and information on iron metabolism from different organisms shows that it is partially preserved but not exactly similar processes (Tang and Zhou, 2013). Although studies on iron metabolism have focused on mammals and yeasts, its mechanism in insects has not been fully elucidated (Tang and Zhou, 2013). Ionic iron (Fe) affects cell development, oogenesis and recovery of oxidative stress in insects (Huebers et al., 1988; Locke and Nichol, 1992; Toru, 1994). Magnesium ion $(\mathrm{Mg})$ has a strong connection with both the innate and acquired immune system (Tam et al., 2003). Mg; it is thought to be related to inflammation, apoptosis, thymocyte gene expression, asthma, and aging (Tam et al., 2003; Barbagallo et al., 2009). Brandao et al. (2013) reported that $\mathrm{Mg}$ regulates homeostasis and activates immune cells in eukaryotes. Selenium (Se) is an essential element for the effective emergence of many features of the immune system in animals and humans (Arthur et al., 2003). Selenium is a powerful antioxidant source that has biological effects by incorporating it into the structure of selenoproteins (Hoffmann and Berry, 2008). Insects are very sensitive to changes in the selenium level, and high levels of Se are harmful to all beneficial and pest insects; however, the average level of $\mathrm{Se}$ is thought to enhance insect immunity (Golubkina et al., 2014). As a result of studies with Drosophila spp, it was determined that Se deficiency decreased the survival rate and egg production (Martin-Romero et al., 2001). Studies on different Lepidoptera species show that Se added to their diet makes these species more resistant to Baculovirus infection (Popham et al., 2005; Shelby and Popham, 2007). In a study conducted with Bombyx mori (Lepidoptera) larva fed with food supplemented with $50 \mu \mathrm{M}$ of Se, it was determined that the elongation of the larval stage of moths increased in the larva, cocoon, and pupa weight and that the number of eggs laid and larvae emerging from the egg was positively affected compared with the control (Jiang et al., 2020).

Different insect species are currently used to evaluate the virulence of pathogens and produce results comparable to those obtained using mammals (Sheehan et al., 2018). Galleria mellonella is used as a model organism in studies related to immunity (Eguchi and Iwabuchi, 2006; Mukherjee et al., 2010; Cook and McArthur, 2013; Senior and Titball, 2020; Piatek et al., 2020). It is preferred because it can be easily reproduced and the results of the applications are obtained rapidly. This study was conducted to evaluate the combined effect of some important metal ions (iron, magnesium and selenium) on innate immunity. For this purpose, G. mellonella encapsulation-melanization immune responses and changes in total hemocyte count were investigated. Metal ions used in this study were equally added to $G$. mellonella artificial food so that the larvae could be exposed to metal ions from the moment they hatched. 


\section{Materials and Methods Insect Rearing}

The G. mellonella (Greater Wax Moth) species used in our study was grown in the Insect Physiology research laboratory of Biology Department, Faculty of Arts and Sciences, Çanakkale Onsekiz Mart University, at $25 \pm 1^{\circ} \mathrm{C}$ and $65 \pm 5 \% \mathrm{RH}$ and 12:12 (L:D) photoperiod condition as described by Kaya et al. (2021a).

\section{Experimental Groups}

Adult moth (4\$2क) taken from the existing colony was taken and placed in a 1-liter glass jar containing $2 \mathrm{gr}$ naturally blackened honeycomb for oviposition surface. After the hatched larvae were seen in this jar, the inorganic mixture obtained with an equal mixture of $\mathrm{Fe}, \mathrm{Mg}$ and $\mathrm{Se}$ in the proportions of $0.1,0.25,0.50$ and 1 (\%) was added to the prepared artificial food. The nutrients of the larvae, which were continuously fed with artificial food (Sak et al., 2006) enriched with inorganic substances, were continuously renewed and fed until they reached the size they were used in the experiment from the moment they first emerged. The last stage larvae that reached the appropriate size $(0.18 \pm 0.02 \mathrm{~g})$ were selected and used in experiments.

\section{Total Hemocyte Count}

In determining the total hemocyte count, the method specified by Kaya et al. $(2021 a, b)$ was used in the study. Accordingly, $4 \mu$ of hemolymph taken from the subjects was placed in a microcentrifuge tube containing $36 \mu \mathrm{l}$ of anticoagulant. Tubes were vortexed for 5 seconds to prevent cell aggregation. Then, $10 \mu \mathrm{l}$ of the anticoagulant-hemolymph mixture was taken from the prepared anticoagulant-hemolymph mixture and loaded on the neuber hemocytometer, and the cell count was made under the phase contrast microscope (Olympus BX-51, Japan).

\section{Encapsulation and Melanization}

The method shown by Kaya et al. $(2021 a, b)$ was used to evaluate the encapsulationmelanization responses in the study. Sephadex A25 chromatography beads were injected into the selected larvae. At the end of the 4 th hour (short period) and 24th hour (long period) after the injection, the larvae were dissected and the beads were collected. The collected beads were examined under a phase-contrast microscope (Olympus BX-51, Japan) to evaluate encapsulationmelanization responses. All the beads were classified according to Richards and Dani (2008) and Er et al. (2010).

\section{Statistic}

Three replicates were performed for each of the hemocyte count, encapsulation and melanization experiments and at all doses, and five larvae were used per replicate. A total of 15 samples were used for each dose in each experiment $(n=15)$. The data obtained from these samples were evaluated by performing one-way ANOVA (Tukey HSD) analysis with the SPSS v20 program $(p<0.05)$.

\section{)}

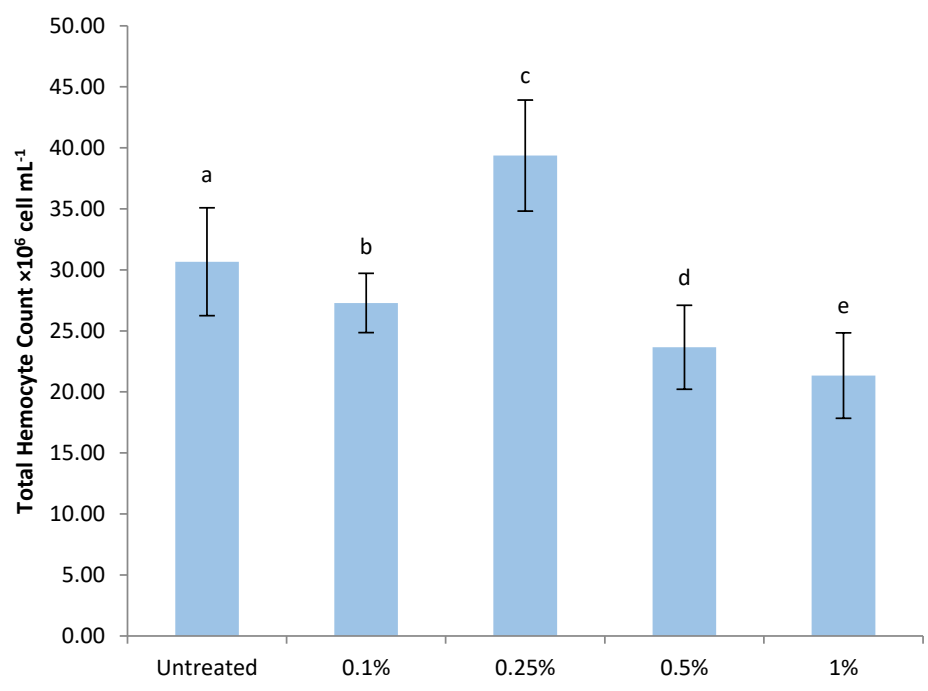

Figure 1. The effect of feeding rich in inorganic substances on the change in the total hemocyte count of $G$. mellonella larvae. The difference between groups with the same letters is insignificant ( $p>0.05)$. A total of 15 samples were evaluated for each dose $(n=15)$. 


\section{Results and Discussions}

The data obtained in the total hemocyte count as a result of the study is shown in Fig 1 . At the end of the study, the total hemocyte count in the control group was found to be $30.67 \times 10^{6}$ cells $\mathrm{mL}^{-1}$. The highest mean of the total hemocyte count was found in the $0.25 \%$ group $\left(39.37 \times 10^{6}\right.$ cells $\mathrm{mL}^{-1}$ ) from the groups fed with food enriched with inorganic substances. The average of all other experimental groups is lower than the control group and the differences of all experimental groups with each other and with the control group were found to be significant (F: 106.694; df: 4; sig:0.000<0.05

The results obtained from the encapsulation responses are shown in Table 1 as a percentage. According to the data obtained, the weak encapsulation response in the $1 \%$ feeding group increased compared to the control, $0.1 \%$ and $0.25 \%$ groups according to the encapsulation results in a short period ( 4 hours). Both the $0.5 \%$ and $1 \%$ feeding groups differ significantly with $0.25 \%$ in terms of weak encapsulation response. While the $0.1 \%$ and $0.25 \%$ groups did not show a significant difference with the control group in terms of strong encapsulation response, it is different from the $0.5 \%$ and $1 \%$ groups. The $1 \%$ group had a significantly lower percentage than the control and $0.5 \%$ groups for both strong and weak encapsulation response (None; F: 0.968; df:4; sig:0.420>0.05) (Weak: F: 5.663; df:4; sig:0.001<0.05) (Strong: F: 11.768; df:4; sig:0.000<0.05).

Table 1. Effect of a diet rich in inorganic substances on the encapsulation response (\%) of G. mellonella larvae at 4 hours and 24 hours after bead injection.

\begin{tabular}{|c|c|c|c|}
\hline \multirow{2}{*}{ Doses } & \multicolumn{3}{|c|}{$4 \mathrm{~h}(\%$ mean $\pm \mathrm{SE})$} \\
\hline & None & Weak & Strong \\
\hline Untreated & $06.78 \pm 2.14^{a}$ & $67.81 \pm 3.10^{\mathrm{ab}}$ & $25.41 \pm 2.59^{\mathrm{ab}}$ \\
\hline $0.1 \%$ & $07.06 \pm 1.76^{a}$ & $64.47 \pm 2.70^{a b}$ & $28.47 \pm 2.76^{b}$ \\
\hline $0.25 \%$ & $06.17 \pm 1.40^{a}$ & $63.62 \pm 1.63^{a}$ & $30.21 \pm 1.78^{b}$ \\
\hline $0.50 \%$ & $07.92 \pm 1.25^{a}$ & $73.18 \pm 1.50^{\mathrm{bc}}$ & $18.91 \pm 1.54^{\mathrm{ac}}$ \\
\hline \multirow[t]{3}{*}{$1 \%$} & $10.49 \pm 1.82^{a}$ & $76.67 \pm 2.04^{c}$ & $12.84 \pm 1.30^{c}$ \\
\hline & \multicolumn{3}{|c|}{$24 \mathrm{~h}(\%$ mean $\pm \mathrm{SE})$} \\
\hline & None & Weak & Strong \\
\hline Untreated & $10.92 \pm 1.37^{a}$ & $29.05 \pm 1.93^{a}$ & $60.03 \pm 2.33^{a}$ \\
\hline $0.1 \%$ & $07.83 \pm 3.04^{a}$ & $28.22 \pm 2.42^{\mathrm{a}}$ & $63.95 \pm 3.31^{\mathrm{a}}$ \\
\hline $0.25 \%$ & $04.58 \pm 1.81^{a}$ & $28.68 \pm 2.42^{\mathrm{a}}$ & $66.74 \pm 2.02^{a}$ \\
\hline $0.50 \%$ & $08.18 \pm 1.87^{a}$ & $67.97 \pm 3.77^{b}$ & $23.85 \pm 3.84^{b}$ \\
\hline $1 \%$ & $11.78 \pm 1.96^{a}$ & $70.75 \pm 1.71^{b}$ & $16.99 \pm 2.75^{b}$ \\
\hline
\end{tabular}


When the data obtained at the end of a long period (24 hours) were examined, while the $0.5 \%$ and $1 \%$ feeding groups did not differ from each other in terms of both weak and strong encapsulation responses, they differed significantly with the control and the $0.1 \%$ and $0.25 \%$ feeding groups. The difference within the control, the $0.1 \%$ and $0.25 \%$ groups was insignificant (None; F: 1.829; df:4; sig:0.133>0.05) (Weak: F: 53.524; df:4; sig:0.000<0.05) (Strong: F: 62.747; df:4; sig:0.000<0.05).

The data on the melanization immune response are shown in Table 2. According to the data obtained in a short period (4 hours), the $0.5 \%$ and $1 \%$ groups had decreased melanization responses compared to the control and the $0.1 \%$, and $0.25 \%$ groups. At the same time, an increase in melanization responses was observed in the $0.1 \%$ nutrition group compared to the control group (non-melanated; F: 24.883; df:4; sig:0.000<0,05) (Melanated: F: 22.559; df:4; sig:0.000<0.05).

When the long-term ( 24 hours) data were examined, the number of melanized beads in the $0.5 \%$ and $1 \%$ groups was lower than all other groups. The control and the $0.25 \%$ and $0.1 \%$ groups did not show a significant difference in melanization responses with each other in this period (non-melanated; F: 63,958; df:4; sig:0,000<0,05) (Melanated: F: 57,639; df:4; sig:0,000<0,05).

Table 2. The effect of a diet rich in inorganic substances on the melanization response (\%) of G. mellonella larvae at 4 hours and 24 hours after bead injection.

\begin{tabular}{|c|c|c|}
\hline \multirow{2}{*}{ Doses } & \multicolumn{2}{|c|}{$4 \mathrm{~h}(\%$ mean $\pm \mathrm{SE})$} \\
\hline & Non-melanated & Melanated \\
\hline Untreated & $78.90 \pm 2.30^{a}$ & $21.10 \pm 2.30^{\mathrm{a}}$ \\
\hline $0.1 \%$ & $70.99 \pm 2.16^{a}$ & $29.01 \pm 2.16^{\mathrm{b}}$ \\
\hline $0.25 \%$ & $75.63 \pm 2.15^{\mathrm{a}}$ & $24.37 \pm 2.15^{\mathrm{ab}}$ \\
\hline $0.50 \%$ & $87.28 \pm 2.25^{b}$ & $12.72 \pm 2.25^{c}$ \\
\hline \multirow[t]{3}{*}{$1 \%$} & $96.03 \pm 1.41^{c}$ & $03.97 \pm 1.41^{d}$ \\
\hline & \multicolumn{2}{|c|}{$24 \mathrm{H}(\%$ mean $\pm \mathrm{SE})$} \\
\hline & Non-melanated & Melanated \\
\hline Untreated & $43.44 \pm 4.78^{a}$ & $56.57 \pm 4.78^{a}$ \\
\hline $0.1 \%$ & $46.60 \pm 2.47^{a}$ & $53.41 \pm 2.47^{\mathrm{a}}$ \\
\hline $0.25 \%$ & $40.84 \pm 2.06^{a}$ & $59.16 \pm 2.06^{a}$ \\
\hline $0.50 \%$ & $85.56 \pm 2.33^{b}$ & $14.44 \pm 2.33^{b}$ \\
\hline $1 \%$ & $95.04 \pm 1.57^{c}$ & $04.96 \pm 1.57^{b}$ \\
\hline
\end{tabular}


Iron, magnesium and selenium inorganic materials used in this study play an active role in the regulation of immunity and various cellular or metabolic events separately according to the literature, but there is no study in which they were evaluated together. In the application of an equal mixture of these metals, which we used in our study, at a dose of $2 \%$, it was determined that the subjects pupated at an early stage ( 3 rd instar), that if $3 \%$ and above, the larvae could not hatch, and that those who could hatch died in a short time. At doses below $1 \%$, it was found that $0.1 \%$ and $0.25 \%$ doses were more effective than other doses in terms of both hemocyte count and encapsulationmelanization responses.

Dunphy et al. (2002) demonstrated that iron ion was essential for early antimicrobial responses in insects. They also stated that iron affected the phenoloxidase enzyme activity, which has an important place in insect immunity, and increased the antimicrobial activity in hemolymph. Iron also affects cell growth, oogenesis, and recovery from oxidative stress in insects (Huebers et al., 1988; Locke and Nichol, 1992; Toru, 1994). Increased intracellular iron levels can promote both cell proliferation and death (Yalçıntepe and Halis, 2016). The term ferroptosis is defined as the type of cell death caused by the iron ion. Ferroptosis depends on intracellular iron, and it differs from apoptosis, necrosis and autophagy morphologically, biochemically and genetically (Dixon et al., 2012). Selenium ion is an important antioxidant and a valuable metal that supports immunity (Hoffmann and Berry, 2008; Reeves et al., 2010). The selenium-dependent glutathione peroxidase is a well-studied enzyme that detoxifies hydrogen peroxides and provides cells or extracellular fluids with a key antioxidant function (Dias et al., 2016). Selenoproteins are identified by the incorporation of Se into the amino acid selenocysteine (Reeves et al., 2010). There are also studies showing that $\mathrm{Se}$ is an essential trace mineral for living things and that high concentrations of Se, however, induces apoptosis and oxidative stress (Qiao et al., 2017). Many factors affecting the immune status may arise from the amount and form of $\mathrm{Se}$ in the individual and the genetic characteristics that affect the Se metabolism of the individual (Avery and Hoffmann, 2018).

Magnesium has been shown to regulate homeostasis and activate immune cells in eukaryotes (Brando et al., 2013). Magnesium has a regulatory role on cell proliferation, cell cycle and cell differentiation (Tam et al., 2003). In addition, magnesium has both structural and enzymatic functions such as participating in the structure of nucleic acids, enzyme activation and inhibition (Tam et al., 2003; Son et al., 2007). It has been demonstrated by various researchers that magnesium deficiency may cause apoptosis (Feng et al., 2011; Trapani et al., 2011).

The total hemocyte count has been evaluated as an important marker in many studies on the immunity of the model organism $G$. mellonella (Er et al., 2010; Altuntaş et al., 2012; Er and Keskin, 2015; Kurt and Kayış, 2015; Gwokyalya and Altuntaş, 2019; Kaya et al., 2021a,b). In the aforementioned literatures, the increase in the number of hemocytes is generally interpreted as supporting immunity. In a study investigating the biochemical, enzymatic and immunological effects of Vitamins $\mathrm{E}$ and Se for $G$. mellonella, it was concluded that the use of Se alone lowered total hemocyte count, which was related to the fact that Se caused apoptosis (Coskun et al., 2020). In the light of the data we obtained in our study, it was seen that feeding rich in inorganic substances (Fe, $\mathrm{Mg}, \mathrm{Se}$ ) increased the number of hemocytes at low doses and caused a decrease in the hemocyte count at high doses. This effect of inorganic substances is related to the involvement of metal ions in the function of enzymes in cell metabolism, which is frequently emphasized in the literature. Intracellular concentration of inorganic substances, especially if the $\mathrm{Mg}$ ion increases the activity of enzymes up to a certain dose, when the threshold value is exceeded, the opposite effect may be preventing the proliferation of cells. In addition, the increase in intracellular iron ion concentration increases cell division as well as induces apoptosis in overdose. This suggests that iron ion uptake above a certain concentration may cause a decrease in hemocyte count. When all the results of our study are evaluated, iron ion stimulates cell division at a certain dose. According to the results of our study, this dose is $0.25 \%$. Applications above this dose cause apoptosis.

It was found that the low doses $(0.1 \%$ and $0.25 \%$ ) used in our study did not cause a significant change in both 4- and 24-hour encapsulation response. However, the high doses $(0.5 \%$ and $1 \%)$ caused a significant decrease in weak and strong encapsulation responses, especially in the long period. Decrease in hemocyte count and malformations of hemocytes are the reasons that prevent encapsulation. The $\mathrm{Fe}$ ion used in our study is thought to both inhibit cell proliferation and lead to apoptosis at high doses. When evaluated together with the change in hemocyte count, the hemocyte count and encapsulation results of our study support each other.

The melanization results of our study may be due to the effect of $\mathrm{Mg}$ ion on intracellular and 
extracellular enzyme activity. The presence of $\mathrm{Ca}$ +2 is an important factor in the activation of the phenoloxidase enzyme. Lee and Anstee (1995) found that $\mathrm{Ca}^{+2}$ and $\mathrm{Mg}^{+2}$ ions were at the optimum level in terms of phenoloxidase activity at the 20-50 mM level and that higher levels of the ion inhibited the enzyme's activity. This is in line with the results we achieved. Fe and Se used in our study may, in a similar way, have an inhibitory effect on enzyme activation at high doses. Selenoprotein is known to regulate calcium metabolism (Reeves et al., 2010). There are also many studies showing that calcium reduces the absorption of iron ions. Although it has not been clarified how this process works, it is possible that iron ions passing into hemolymph prevent the release of calcium ions (Lynch, 2000). This can be interpreted with the explanation that the phenoloxidase enzyme inhibits the completion of the melanization process by stopping the biochemical steps in the melanization process.

\section{Conclusions}

In this study, the effects of feeding rich in inorganic substances on the model organism $G$. mellonella hemocyte and hemocyte-mediated immune responses were determined. At the beginning of the study, feeding trials over $1 \%$ up to $10 \%$ were made. However, initial studies showed that the larvae could not hatch from the eggs at doses above $2 \%$, and at the $2 \%$ dose, it was observed that the larvae turned into pupae in the first stages (3rd instar) and the moths that emerged from the pupa were smaller than the control group and could not reproduce.

When all the experimental results of our study are evaluated together, it is seen that a diet rich in inorganic substances can support immunity up to $0.25 \%$, while higher doses will have the opposite effect. In the literature, it was stated that Fe and Se induced apoptosis and reduced the number of hemocytes in G. mellonella; however, the data we obtained in terms of total hemocyte count in our study showed that when $\mathrm{Fe}$, Se and Mg were taken at a certain rate and in balance, the number of hemocytes could increase. Although this is a result obtained in insects, it may suggest that similar effects may occur in other living groups.

Another result of our study is that using Fe, Se and $\mathrm{Mg}$ together is more effective than using them individually. It is better to test a system in which ions important to the immune system are together than to test each ion individually. Because enzymatic systems can work in a homeostatic system with all the apoenzymes and coenzymes they need. Accordingly, even if there is a decrease in hemocyte numbers, it was determined that they strengthened immune responses in the direction of hemocyte behavior (encapsulation-melanization responses). However, feeding a diet enriched with $\mathrm{Fe}$, Se and $\mathrm{Mg}$ at doses higher than $2 \%$ completely stops the development of $G$. mellonella. In addition, in the $2 \%$ enriched food, the development of G. mellonella partially stopped and the larvae tended to pupate in the 3rd and 4th stages. This result means that excessive intake of $\mathrm{Fe}$, Se and Mg will impair the development of living things and inhibit their life functions.

Hemocyte count, encapsulation and melanization responses are among the most suitable parameters for determining basic immune responses. However, the data obtained from these parameters should be supported by biochemical and enzymatic and genotoxic studies. In this way, it will be possible to understand the changes in hemocyte count, encapsulation and melanization responses in more depth.

\section{Acknowledgements}

This work was supported by The Scientific Research Coordination Unit of Çanakkale Onsekiz Mart University, Turkey (Project number: FBA-20182521).

Conflict of Interest Statement: Article authors declare that there is no conflict of interest between them.

Contribution Rate Statement Summary: The authors declare that they have contributed equally to the article.

\section{References}

Altuntaş, H., Kılıç, A. Y., Uçkan, F. and Ergin, E. 2012. Effects of gibberellic acid on hemocytes of Galleria mellonella L. (Lepidoptera: Pyralidae). Environmental Entomology, 41(3): 688-696.

Anastassopoulou, J. and Theophanides, T. 1995. The Role of Metal Ions in Biological Systems and Medicine. Pp 209-218. In: Kessissoglou, D.P. (eds) Bioinorganic Chemistry. NATO ASI Series (Series C: Mathematical and Physical Sciences), vol 459. Springer, Dordrecht. pp415

Arthur, J. R., McKenzie, R. C. and Beckett, G. J. 2003. Selenium in the immune system. The Journal of Nutrition, 133(5): 1457-1459.

Avery, J. C. and Hoffmann, P. R. 2018. Selenium, selenoproteins, and immunity. Nutrients, 10(9): 1203. 
Barbagallo, M., Belvedere, M. and Dominguez, L. J. 2009. Magnesium homeostasis and aging. Magnesium Research, 22(4): 235-246.

Brandao, K., Deason-Towne, F., Perraud, A. L. and Schmitz, C. 2013. The role of $\mathrm{Mg}^{2+}$ in immune cells. Immunologic Research, 55(13): 261-269.

Cook S. M. and McArthur J. D. 2013. Developing Galleria mellonella as a model host for human pathogens. Virulence, 4: 350-353.

Coskun, M., Kayis, T., Gulsu, E., and Alp, E. (2020). Effects of Selenium and Vitamin $E$ on Enzymatic, Biochemical, and Immunological Biomarkers in Galleria mellonella $\mathrm{L}$. Scientific Reports, 10(1), 1-7.

Cutuli, M. A., Petronio Petronio, G., Vergalito, F., Magnifico, I., Pietrangelo, L., Venditti, N., and Di Marco, R. 2019. Galleria mellonella as a consolidated in vivo model hosts: New developments in antibacterial strategies and novel drug testing. Virulence, 10(1): 527-541.

Dias, F. A., Gandara, A. C., Perdomo, H. D., Gonçalves, R. S., Oliveira, C. R., Oliveira, R. L., Citelli, M., Polycarpo, C. R., Santesmasses D., Mariotti, M., Guigó, R., Braz, G. R., Missirlis, F. and Oliveira, P. L 2016. Identification of a selenium-dependent glutathione peroxidase in the blood-sucking insect Rhodnius prolixus. Insect Biochemistry and Molecular Biology, 69: 105-114.

Dixon, S. J., Lemberg, K. M., Lamprecht, M. R., Skouta, R., Zaitsev, E. M., Gleason, C. E., Patel, D. N., Bauer, A. j., Cantley, A. M., Yang, W. S., Morrison, B. and Stockwell, B. R. 2012. Ferroptosis: an iron-dependent form of nonapoptotic cell death. Cell, 149(5): 1060-1072.

Dubovskiy, I. M., Kryukova, N. A., Glupov, V. V. and Ratcliffe, N. A. 2016. Encapsulation and nodulation in insects. Invertebrate Survival Journal, 13(1): 229-246.

Dunphy, G. B., Niven, D. F. and Chadwick, J. S. 2002. Iron contributes to the antibacterial functions of the haemolymph of Galleria mellonella. Journal of Insect Physiology, 48(9): 903-914.

Eguchi D. and Iwabuchi K. 2006. A new cell line from the wax moth Galleria mellonella Linne (Lepidoptera: Pyralididae). In Vitro Cellular and Developmental Biology-Animal, 42: 1-3.

Er, A. and Keskin, M. 2015. Influence of abscisic acid on the biology and hemocytes of the model insect Galleria mellonella (Lepidoptera: Pyralidae). Annals of the
Entomological Society of America, 109(2): 244-251.

Er, A., Uçkan, F., Rivers, D. B., Ergin, E. and Sak, O. 2010. Effects of parasitization and envenomation by the endoparasitic wasp Pimpla turionellae (Hymenoptera: Ichneumonidae) on hemocyte numbers, morphology, and viability of its host Galleria mellonella (Lepidoptera: Pyralidae). Annals of the Entomological Society of America, 103(2): 273-282.

Feng, H., Guo, L., Gao, H. and Li, X. A. 2011. Deficiency of calcium and magnesium induces apoptosis via scavenger receptor BI. Life Sciences, 88(13-14): 606-612.

Golubkina, N., Sheshnitsan, S. and Kapitalchuk, M. 2014. Ecological importance of insects in selenium biogenic cycling. International Journal of Ecology, Article ID 835636

Gwokyalya, R. and Altuntaş, H. 2019. Boric acidinduced immunotoxicity and genotoxicity in model insect Galleria mellonella $\mathrm{L}$. (Lepidoptera: Pyralidae). Archives of Insect Biochemistry and Physiology, e21588.

Hillyer, J. F. 2016. Insect immunology and hematopoiesis. Developmental and Comparative Immunology, 58: 102-118.

Hoffmann, P. R. and Berry, M. J. 2008. The influence of selenium on immune responses. Molecular Nutrition and Food Research, 52(11): 1273-1280.

Huebers, H. A., Huebers, E., Finch, C. A., Webb, B. A., Truman, J. W., Riddiford, L. M., Martin, A.V. and Massover, W. H. 1988. Iron binding proteins and their roles in the tobacco hornworm, Manduca sexta (L.). Journal of Comparative Physiology B, 158(3): 291-300.

Jiang, L., Peng, L. L., Cao, Y. Y., Thakur, K., Hu, F., Tang, S. M. and Wei, Z. J. 2020. Effect of Dietary Selenium Supplementation on Growth and Reproduction of Silkworm Bombyx mori L. Biological Trace Element Research, 193(1): 271-281.

Kaya, S., Akkuş, G., Türkdoğan, S., and Gündüz, B. 2021a. Influence of Helichrysum arenarium on hemocyte-mediated immune responses and phenoloxidase enzyme activity of model organism Galleria mellonella (L.). International Journal of Tropical Insect Science, 1-8. Doi: 10.1007/s42690-02100432-8

Kaya, S., Uçkan, F. and Er, A. 2021b. Influence of Indole-3-Acetic Acid on Cellular Immune Responses of Galleria mellonella $\mathrm{L}$. (Lepidoptera: Pyralidae) and Pimpla turionellae L. (Hymenoptera: Ichneumonidae) in a host-parasitoid system. 
International Journal of Tropical Insect Science, 41(1): 169-179.

Krautz, R., Arefin, B. and Theopold, U. 2014. Damage signals in the insect immune response. Frontiers in Plant Science, 5: 342.

Kurt, D. and Kayış, T. 2015. Effects of the pyrethroid insecticide deltamethrin on the hemocytes of Galleria mellonella. Turkish Journal of Zoology, 39(3): 452-457.

Lavine, M.D. and Strand, M.R. 2002. Insect hemocytes and their role in immunity, Insect Biochemistry and Molecular Biology, 32: 1295-1309.

Lee, M. J. and Anstee, J. H. 1995. Phenoloxidase and its zymogen from the haemolymph of larvae of the lepidopteran Spodoptera littoralis (Lepidoptera: Noctuidae). Comparative Biochemistry and Physiology Part B: Biochemistry and Molecular Biology, 110(2): 379-384.

Locke, M. and Nichol, H. 1992. Iron economy in insects: transport, metabolism, and storage. Annual Review of Entomology, 37(1): 195215.

Lynch, S. R. 2000. The effect of calcium on iron absorption. Nutrition Research Reviews, 13(2): 141-158.

Martin-Romero, F. J., Kryukov, G. V., Lobanov, A. V., Carlson, B. A., Lee, B. J., Gladyshev, V. N. and Hatfield, D. L. 2001. Selenium metabolism in Drosophila: selenoproteins, selenoprotein mRNA expression, fertility, and mortality. Journal of Biological Chemistry, 276(32): 29798-29804.

Mukherjee, K., Altincicek, B., Hain, T., Domann, E., Vilcinskas, A. and Chakraborty, T. 2010. Galleria mellonella as a Model System for Studying Listeria Pathogenesis. Applied and Environmental Microbiology, 76 (1): 310317.

Nappi, A. J. and Christensen, B. M. 2005. Melanogenesis and associated cytotoxic reactions: applications to insect innate immunity. Insect Biochemistry and Molecular Biology, 35(5): 443-459.

Qiao, B., He, B., Cai, J., Lam, A. K. Y. and He, W. 2017. Induction of oxidative stress and cell apoptosis by selenium: the cure against oral carcinoma. Oncotarget, 8(69): 113614113621.

Pech, L. L. and Strand, M. R. 1996. Granular cells are required for encapsulation of foreign targets by insect haemocytes. Journal of Cell Science, 109(8): 2053-2060.

Piatek, M., Sheehan, G. and Kavanagh, K. 2020. Utilising Galleria mellonella larvae for studying in vivo activity of conventional and novel antimicrobial agents. Pathogens and Disease, 78(8): ftaa059.

Popham, H. J., Shelby, K. S., and Popham, T. W. 2005. Effect of dietary selenium supplementation on resistance to baculovirus infection. Biological Control, 32(3): 419-426.

Reeves, M. A., Bellinger, F. P. and Berry, M. J. 2010. The neuroprotective functions of selenoprotein $M$ and its role in cytosolic calcium regulation. Antioxidants and Redox Signaling, 12(7): 809-818.

Richards, E. H. and Dani, M. P. 2008. Biochemical isolation of an insect haemocyte antiaggregation protein from the venom of the endoparasitic wasp, Pimpla hypochondriaca, and identification of its gene, Journal of Insect Physiology, 54: 10411049

Rosales, C. (2011). Phagocytosis, a cellular immune response in insects, Invertebrate Survival Journal, 8: 109-131.

Sak, O., Uçkan, F. and Ergin, E. 2006. Effects of cypermethrin on total body weight, glycogen, protein, and lipid contents of Pimpla turionellae (L.) (Hymenoptera: Ichneumonidae), Belgian Journal of Zoology, 136: 53-58.

Senior, N. J. and Titball, R. W. 2020. Isolation and primary culture of Galleria mellonella hemocytes for infection studies. F1000Research, 9: 1392.

Sheehan, G., Garvey, A., Croke, M. and Kavanagh, K. 2018. Innate humoral immune defences in mammals and insects: The same, with differences?. Virulence, 9(1): 1625-1639.

Shelby, K. S. and Popham, H. J. 2007. Increased plasma selenium levels correlate with elevated resistance of Heliothis virescens larvae against baculovirus infection. Journal of Invertebrate Pathology, 95(2): 77-83.

Son, E. W., Lee, S. R., Choi, H. S., Koo, H. J., Huh, J. E., Kim, M. H. and Pyo, S. 2007. Effects of supplementation with higher levels of manganese and magnesium on immune function. Archives of Pharmacal Research, 30(6): 743-749.

Sorvari, J., Hakkarainen, H. and Rantala, M. J. 2014. Immune defense of ants is associated with changes in habitat characteristics. Environmental Entomology, 37(1): 51-56.

Tam, M., Gomez, S., Gonzalez-Gross, M. and Marcos, A. 2003. Possible roles of magnesium on the immune system. European Journal of Clinical Nutrition, 57(10): 1193-1197. 
Tang, X. and Zhou, B. 2013. Iron homeostasis in insects: Insights from Drosophila studies. IUBMB Life, 65(10): 863-872.

Tassetto, M., Kunitomi, M. and Andino R. 2017. Circulating immune cells mediate a systemic RNAi based adaptive antiviral response in Drosophila. Cell, 169 (2): 314-325.

Trapani, V., Mastrototaro, L. and Wolf, F. I. 2011. Magnesium and the Yin--Yang interplay in apoptosis. pp. 85-98. In: Nechifor, M. and Vink, R. (Eds). Magnesium in the Central
Nervous System vol 85. University of Adelaide Press. $x x x+356$ pp.

Toru, A. 1994. Superoxide generation in vitro in lepidopteran larval haemolymph. Journal of Insect Physiology, 40(2): 165-171.

Yalçıntepe, L. and Halis, E. 2016. Modulation of iron metabolism by iron chelation regulates intracellular calcium and increases sensitivity to doxorubicin. Bosnian Journal of Basic Medical Sciences, 16(1): 14. 